Марко Драшковић

Византолошки институт САНУ

marko.draskovich@gmail.com
Оригиналан научни рад

примљено: 1. јул 2012

прихваћено: 1. октобар 2012

\title{
ВАРЕШКИ НАЈАМНИЦИ КАО ТЕЛОХРАНИТЕЉИ КОМНИНСКИХ ЦАРЕВА*
}

Сажетак: на основу византијских и западних извора, рад реконструише основне особености телохранитељске службе скандинавских најамника у Византији комнинског доба (1081-1185), укључујући најсроднија питања.

Кључне речи: средњовековни најамници, XII век, Варези, византијска војска.

Нордијски најамници, у византијским изворима познати најчешће под

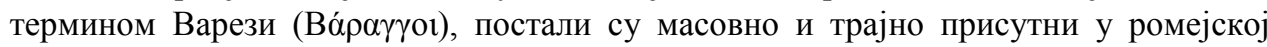
војсци од краја X века, када је Василије II за њих формирао посебну тагму царске стајаће војске. Током друге половине XI века, у састав варешке тагме ушли су и англосаксонски исељеници. ${ }^{1}$ Битно је истаћи да су и нордијски и англосаксонски најамници служили, пре свега, као тешка пешадија, за разлику од осталих западних најамника у византијској служби, ${ }^{2}$ који су најчешће служили као тешка коњица (италијански Нормани, Французи, Немци, Ломбарђани).

\footnotetext{
* Овај рад настао је у склопу пројекта Министарства науке Републике Србије Традиција, иновација и идентитет у византијском свету (пројекат број 177032).

${ }^{1}$ Основну реконструкцију присуства нордијских најамника у целокупној византијској историји дао је Sigfus Blöndal, The Varangians of Byzantium. An aspect of Byzantine military history, tr. and rev. Benedikt Benedikz, Cambridge 1978. (=S. Blöndal, Varangians) (са прегледом старије литературе о англосаксонским најамницима); за општу слику о нордијским најамницима у доба Комнина в. Марко Драшковић, Етничко-регионална, персонално-просопографска и соиијална структура нордијских најамника у комнинској Византији, Војноисторијски гласник 2011-1, 9-30 (са прегледом извора); за византијске вареге предкомнинског периода битна је студија: Dion Smythe, Why do barbarians stand round the emperor at diplomatic receptions?, Byzantine diplomacy, ed. J. Shepard - S. Franklin, Cambridge 1990, 305-312 (= D. Smythe, Barbar.); Нордијаца у Византији XI века дотиче се најбогатија општа студија западних најамника у Византији XI века: Jean-Claude Cheynet, Le role des Occidentaux dans l'armée byzantine avant la Première Croisade, Byzanz und das Abendland im 10. und 11. Jahrhundert, ed. E. Konstantinou, Wien 1997, 111-128. (=J. Cheynet, Occident.)

2 Поред поменуте Шенеове студије, за општу слику о континенталним западним најамницима у Византији XI и XII века корисна је: Robert Janin, Les Francs au service des Byzantins, Echos d`Orient 29,
} 
Нордијски и остали западноевропски најамници имали су у византијској војсци различите војне функције, од којих су најчешће биле служба у царевим телохранитељским јединицама, гарнизонска служба у тврђавама и учешће у експедиционим војскама. Ове три функције такође су имале изворне, домаће византијске тагме. Пошто су западни најамници били континуирано плаћани, цар их је у било ком тренутку могао пребацити с једне војне функције на другу, тако да се дешавало да нордијски телохранитељи и франачке гарнизонске трупе буду послати у саставу експедиционе војске. И по том питању, ови најамници били су слични домаћим тагмама.

Пре комнинског доба, међу самим Варезима постојала је подела на Градске (тј. престоничке) и Ванградске (тј. провинцијске) Вареге. ${ }^{3}$ Ванградски Варези коришћени су у своје војне сврхе широм царства, па су тек они који се истакну у таквој служби били примани међу престоничке Вареге. ${ }^{4}$ Таква пракса вероватно је постојала и у комнинско доба, и вероватно је примењивана и на Англосаксонце. ${ }^{5}$

У овом раду, на основу доступних ваизантијских и западних извора, покушаћу да реконструишем основне особености телохранитељске функције нордијских најамника за владе дома Комнина (1081-1185), укључујући и оне сродне функције Варега које су, по природи ствари, биле уско везане за телохранитељску функцију у ужем смислу (чување царских палата, церемонијална стража, учешће у хапшењу).

\section{Царски телохранитељи (у најужем смислу)}

Најистакнутија функција коју су нордијски (а касније и англосаксонски) најамници вршили у византијској војсци била је телохранитељска служба цару. Испољавала се, пре свега, у пракси да јединица варешких телохранитеља прати автократора где год би он ишао, физички га штитећи од свих опасности тако што би најодабранији варешки телохранитељи формирали живи обруч око цара. Ову праксу, видљиву током читавог времена постојања варешке тагме у Византији, уочићемо и у изворима комнинског доба. Осим тога, присуство варешких телохранитеља било је један од симбола легитимног автократора. ${ }^{6}$ Чини ми се да је Нордијце за место царских телохранитеља додатно препоручивала и околност да су многи од њих пре одласка у Византију служили као телохранитељи својим

1930, 61-72; занимљаива просопографска анализа латинских најамника у Византији XI века, која улази делом и у XII век, јесте: Alexander Kazhdan, Latins and Franks in Byzantium: Perception and Reality from the Eleventh to the Twelfth Century, The Crusades from the Perspective of Byzantium and the Muslim World, ed. A. Laiou and R. Parviz Mottahedeh, Dumbarton Oaks 2001, 83-100.

${ }^{3}$ S. Blöndal, Varangians, 28.

${ }^{4}$ S. Blöndal, Varangians, 45; Исти, Nabites the Varangian. With some notes on the Varangians under Nicephorus III Botaniates and the Comneni, Classica et Mediaevalia 2, 1939, 145-167 (=S. Blöndal, Nabites, 159).

${ }^{5}$ S. Blöndal, Nabites, 157.

${ }^{6}$ D. Smythe, Barbar., 311-312. Аутор је ову тврдњу показао, пре свега, на подацима из византијских извора предкомнинског периода. 
краљевима и вођама, будући да је у нордијским земљама вековима био обичај да истакнути ратници служе као телохранитељи краљева и јарлова. ${ }^{7}$ Ови телохранитељи чували су своје нордијске господаре тако што су око њих формирали живи Штитни зид, ${ }^{8}$ што их је посебно чинило корисним и за физичку заштиту византијског цара.

Варешки телохранитељи се као физички заштитници царева појављују већ у доба царице Зоје, када су наоружани секирама и штитовима окруживали ову царицу и њену сестру Теодору. ${ }^{9}$ Наоружани истим оружјем они су окруживали и Исака Комнина, пошто се он прогласио за цара. ${ }^{10}$ Када се после битке код Манцикерта Михаило VII уплашио да му синови Романа IV не преотму власт, Варези наоружани секирама и штитовима око њега су формирали живи обруч. ${ }^{11}$

У комнинско доба, Варези се као царски телохранитељи помињу најпре у склопу приповести Ане Комнине о доласку Алескија I на власт: она каже да је цезар Јован Дука саветовао Алексију да не покушава да подмити Вареге, јер они заштиту царева сматрају светом обавезом и наслеђем својих предака. ${ }^{12}$ Ана, међу комнинским изворима, најизричитије помиње уобичајену кружну формацију којом су варешки телохранитељи чували њеног оца и василевса. Наиме, говорећи о покушајима Нићифора Диогена (1094) да убије њеног оца, Ана каже да су Алексија од окупљене масе заштитили царски телохранитељи наоружани ромфејама, ${ }^{13}$ и то тако што су се око царског трона распоредили у облику полумесеца, обухватајући цара као раширеним рукама. ${ }^{14}$ Праксу да варешки телохранитељи штите василевса од масе, и то при кретању кроз град, јасно видимо и код Јована Кинама, у случају тријумфалног уласка Манојла I у Антиохију (1159) - упозорен да се неки Антиохити спремају да га убију, овај василевс је одговорио да ће га при уласку у град пратити, као што је уобичајено, велика дружина пелекофора. ${ }^{15}$ Праксу да Варези-телохранитељи прате василевса на војним походима, и да у кружној формацији штите василевсов шатор, јасно можемо видети из фрагмената о чудима

\footnotetext{
${ }^{7}$ Saga Sverris Konungs, Kaupmannahöfn 1834, 149 (= Sver.); P. H. Sawyer, Kings and Vikings. Scandinavia and Europe 700-1100, London 2003, 47-56.

${ }^{8}$ Charles Oman, A History of the Art of War. The Middle Ages from the Fourth to the Fourteenth Century, London 1898, 97-98. (= C. Oman, War). Штитни зид се, у принципу, формирао преклапањем округлих и овалних нордијских штитова приближно на половини њихових дијаметара; Штитни зид, сам по себи, био је основна бојна формација Норвежана и Швеђана пре средине ХІІІ века.

${ }_{9}^{9}$ D. Smythe, Barbar., 307; S. Blöndal, Varangians, 103. Сама по себи, тзв. Данска секира била је основни елемент офанзивног наоружања код Норвежана и Швеђана (барем до почетка XIII века) и Данаца (барем до средине XII века). Њена дршка износила је најчешће барем две трећине висине ратника, што јој је омогућавало да парира не само мачевима, него и копљима.

${ }^{10}$ D. Smythe, Barbar., 306; S. Blöndal, Varangians, 108.

${ }^{11}$ S. Blöndal, Varangians, 114.

${ }^{12}$ Annae Comnenae Alexias, ed. D. R. Reinsch et A. Kambylis, vol. I (textus), Berlin 2001, 79. (=Alexias)

${ }^{13}$ Ромфеја је била карактеристично оружје Варега, али је њен конкретан изглед остао предмет спора у науци. Извесно је само то да византијски извори XI и XII века везују њу готово увек за Вареге.

${ }^{14}$ Alexias, 277.

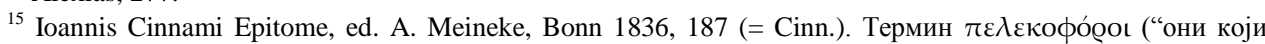
носе секире“) јесте главни синоним којим византијски извори означавају Вареге у служби василевса Ромеја.
} 
норвешког св. краља Олафа, које је Снори Стурлусон укључио у своје биографије нордијских краљева. Наиме, у причи о чуду са мачем св. Олафа, Снори приказује Вареге како чувају стражу око царевог шатора (василевса Јована II), у логору, за време војног похода; он каже да су том приликом Варези поделили ноћ на деонице стражарења, тако да један за другим чувају стражу, док остали спавају. Уз то, Снори истиче да Варези имају обичај да спавају на земљи под пуним оклопом, тако што шлем држе на глави, штитом покрију тело, а мач ставе под главу, са десном руком преко балчака. Тако је спавао и стражарио и Варег који је поседовао мач св. Олафа. ${ }^{16}$ Пракса да Варези-телохранитељи прате цара и у самој бици, али и да их василевс у служају нужде може послати да се попут обичних војника боре у отвореној бици, види се такође из следећих фрагмената Кинама, Хонијата и Снорија који се односе на битку код Старе Загоре (1122). ${ }^{17}$ Наиме, Кинам истиче да је пелекофорима, који су се налазили око њега, цар Јован II наредио да нападну Ските. ${ }^{18}$ Слично томе, Хонијат напомиње да је цар овде у борбу послао своје личне штитоноше $(\dot{v} \pi \alpha \sigma \pi \imath \tau \alpha \dot{s})^{19}$. За разлику од њих, Снори тврди да се заповедник Варега, по имену Тори, сам понудио да са својим сународницима нападне непријатеља, кунући се да би са својим људима за цара скочио у ватру, и позивајући у помоћ св. краља Олафа. Додуше, Торијева понуда уследила је пошто су франачки коњаници-најамници саопштили цару да у битку треба да пошаље своје винопије, то јест Вареге. Овај Стурлусонов податак о алкохолизму комнинских варегателохранитеља налази потврду и у делу Сакса Граматика. Сноријев податак да је у овој бици било 540 Нордијаца, ${ }^{20}$ Блендалу је послужило као основ за хипотезу да је одред Варега-телохранитеља који прате цара бројао око 500 људи. ${ }^{21}$ Уз то, могуће је да је одреду царевих варешких телохранитеља припадао и норвешки племић Ендриди, с обзиром да је средином XII века служио у самом Цариграду ${ }^{22}$ и да је постао царев дворанин од поверења. ${ }^{23}$

У мање повољном светлу од византијских извора, али не са мање живописних детаља, и Саксо Граматик помиње Вареге-телохранитеље комнинских царева, и то данске телохранитеље-плаћенике који су служили Алексију I у време када је дански краљ Ерик I Добри посетио Цариград (1102). Наиме, том приликом краљ Ерик састао се са Алексијевим данским телохранитељима и замерио им да се превише опијају вином, које их чини аљкавим и свадљивим. Као њихов највећи грех, краљ је царевим Данцима замерио кукавичлук, исказан кроз њихову склоност да беже у бици (што се вероватно односи на држање једног дела Варега у бици за

\footnotetext{
${ }^{16}$ Snorri Sturluson, Heimskringla, ed. F. Jonsson, Copenhagen 1911, 611. (=Heimskringla)

${ }^{17}$ У овој бици, као што је познато, ромејска и најамничка латинска тешка коњица нису успеле да потуку куманско-печенешку лаку коњицу; тек јуриш варешке тешке пешадије успео је да је сломи и ову битку претвори у византијску победу.

${ }^{18}$ Cinn., 8.

${ }^{19}$ Nicetae Choniatae Historia, ed. J. L. van Dieten, Berlin 1975, 15. (= Chon.)

${ }^{20}$ Heimskringla, 612.

${ }^{21}$ S. Blöndal, Nabites, 162; Исти, Varangians, 181.

${ }^{22}$ Heimskringla, 611.

${ }^{23}$ Ibid., 582.
} 
Драч 1081) и закључио да они своја места царских телохранитеља дугују добром гласу својих претходиника-сународника, а не сопственим квалитетима. ${ }^{24}$

Англосаксонци су такође укључивани међу варешке телохранитеље. Пелекофоре који су код Старе Загоре (1122) стајали око цара Кинам је назвао

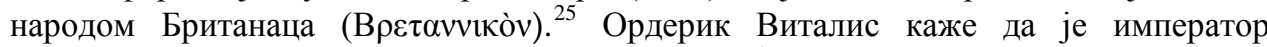
Алексије учинио Англе чуварима своје личности. ${ }^{26}$ Ови Англи пре тога служили су у саставу ромејске војске која се 1082 . борила код Драча, и као гарнизонске трупе града Кивота, ${ }^{27}$ због чега постоји претпоставка да је део Англа, који су служили широм царства, Алексије унапредио у своје телохранитеље, и то пре свега зато јер је у бици за Драч изгубио велики део својих нордијских телохранитеља. ${ }^{28}$ Анонимна лаонска хроника такође каже да је Алексије поставио Англе за чуваре његове личности и царске породице. ${ }^{29}$ Чини ми се да је Англосаксонце за место царских телохранитеља препоручивала и околност да су многи од њих пре 1066. служили као телохранитељи својих краљева и великаша, било као хускарли, било као тенови.

Важно је претпоставити да су нордијски телохранитељи улазили не само у састав варешке телохранитељске јединице, него и у састав ужих телохранитељских одреда који су имали карактер цареве уже војне пратње. Такав каратер имали су у

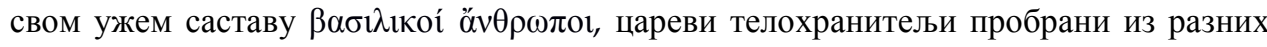
домаћих и страних јединица на основу величине и снаге. Њихови официри имали су звања спатарокандидата и спатарија. ${ }^{30}$ Уздизање страних најамника, Варега и Франака, у ранг спатарија и спатарокандидата, помиње текст савета цара приписан Кекавмену. ${ }^{31}$ Својевремено, за своје учешће у гушењу Дељановог устанка, звањем спатарокандидата био је награђен принц Харалд. ${ }^{32}$ Роман IV укључио је неке Немце у своју личну гарду, али их је ускоро искључио из ње због њихове недисциплине. ${ }^{33}$

Друга ужа гардијска група, у коју су Варези могли ући, јесте Велика хетерија. Њени чланови бирани су често међу царевим страним телохранитељима. ${ }^{34}$ Тачни задаци Велике хетерије нису у науци сасвим утврђени, али је извесно да је у

\footnotetext{
${ }^{24}$ Saxonis Grammatici Gesta Danorum, ed. A. Holder, Strassburg 1886, 407. (= Saxo)

${ }^{25}$ Cinn., 8.

${ }^{26}$ Orderici Vitalis Historiae Ecclesiasticae, ed. A. Le Prevost, Paris 1838-55 (= Order.), vol. III, 169.

${ }^{27}$ Ibid., vol. II, 172.

${ }^{28}$ S. Blöndal, Nabites, 157; Alexander Vasiliev, The Opening stages of the Anglo-saxon immigration to Byzantium in the eleventh century, Annales de l'institut Kondakov IX, Praha 1937, 58. (= A. Vasiliev, Immigration).

${ }^{29}$ Фрагменте Лаонске опште хронике (Chronicon universale anonymi Laudunensis), који се односе на англосаксонску емиграцију у Цариграду, објавила је Krijna Ciggaar у оквиру своје студије L'émigration anglaise a Byzance après 1066: Un nouveau texte en latin sur les Varangues à Constantinople, Revue des études Byzantines 32, Paris 1974, 321-323.

${ }^{30}$ Michael Angold, The Byzantine Empire 1025-1204. A political history, London-New York 1984, 213 (= M. Angold, Empire); Warren Treadgold, Byzantium and its Army 284-1081, Stanford 1995, 135. (=W. Treadgold, Army)

${ }^{31}$ Советы и рассказы Кекавмена, Москва 1972, ed. Г. Литаврин, 278, 280.

${ }^{32}$ S. Blöndal, Varangians, 58.

${ }^{33} \mathrm{~J}$-C. Cheynet, Occident., 116.

${ }^{34} \mathrm{~W}$. Treadgold, Army, 110.
} 
њих спадало чување појединих палата, као и чување царевог или војсковођиног шатора за време похода. ${ }^{35}$

Поставља се питање да ли је у ромејској држави још неко осим цара имао право на варешке телохранитеље у својој пратњи. Познато је да је Михаило VIII сматрао да његов син Андроник има у својству савладара право на сопствене варешке телохранитеље, ${ }^{36}$ али је на основу тога немогуће закључити да ли је савладар у комнинско доба имао такво право. Царица је и пре комнинског доба имала сопствене, домаће византијске телохранитеље, ${ }^{37}$ али то не значи да је имала право и на сопствене Вареге. У доба Палеолога, одреди Варега-телохранитеља били су понекад додељивани царевој браћи (као нпр. Јовану, брату Михаила VIII), ${ }^{38}$ али у XI и XII веку не налазимо такву праксу.

\section{Чувари царских палата}

Природно и практично везана за њихову телохранитељску функцију, била је служба Варега као сталних чувара царских палата. У доба Комнина, Варези су чували две најважније цариградске палате, Велику палату и Влахерну.

Велика палата је и у доба Комнина наставила да игра своју вековну улогу административног средишта царства. У њој је цар најчешће примао највише чиновнике царства и стране изасланике; Манојло I изградио је у њој нову престону дворану. У њој су се налазиле и царске инсигније и седиште ковнице новца, а испод ње биле су смештене спиралне галерије са државним резервама новца. ${ }^{39}$ У комплекс Велике палате спадале су и пекаре, цистерне, амбари, кројачке и златарске занатске радње и штале, а била је посебним бедемом одвојена од остатка Цариграда, што ју је чинило градом унутар града. ${ }^{40}$

У комплексу Велике палате, Варези су имали своје станове у Екскубити коју су чиниле зграде изграђене уз бедем који је делио комплекс палате од остатка града. Овде је вероватно и била смештена већина цариградских Варега. Ове станове делили су са припадницима домаће византијске тагме екскубита. ${ }^{41}$ Станујући близу ових бедема, Варези су са екскубитима чували прилаз Великој палати. Да је тако било и доба Комнина, види се из Зонарине приповести о доласку Јована II на власт. Док је Алексије I био на самрти, Варези су држали пут кроз Екскубиту и никога нису хтели да пусте у Велику палату, па ни Јована; овде Зонара напомиње да су се у Екскубити налазили станови Варега. Тек кад им је Јован показао очев печатни прстен, Варези су му отворили капије Велике палате. ${ }^{42}$

\footnotetext{
${ }^{35}$ S. Blöndal, Varangians, 178.

${ }^{36}$ Mark Bartusis, The Late Byzantine Army. Arms and Society 1204-1453, Philadelphia 1992, 283. (= M. Bartusis, Army)

${ }^{37}$ Мери МекКормик, Цар, Византинци, прир. Г. Кавало, Београд 2006, 305. (=М. МекКормик, Цар)

${ }^{38}$ S. Blöndal, Varangians, 179.

${ }^{39}$ M. Angold, Empire, 211.

${ }^{40}$ М. МекКормик, Цар, 291.

${ }^{41}$ S. Blöndal, Varangians, 19.

${ }^{42}$ Ioannis Zonarae Epitomae Historiarum, vol. III, ed. T. Büttner-Wobst, Bonn 1897, 763.
} 
Варези су, заједно са припадницима домаћих византијских тагми, чували поједине дворане у комплексу Велике палате, па су зато у њиховој близини имали своје стражарске собе. ${ }^{43}$

Природно, Варези су чували и палату Влахерну, која је у доба Комнина била царска резиденција и породично утврђење владајуће динстије; у њој се збивала већина догађаја битна за породични живот Комнина. ${ }^{44}$ Ова палата била је битна и зато јер су се у њеној четврти налазиле палате царских рођака и највиших аристократа. $^{45}$ У комнинско доба, не помињу се стражарске собе варешких телохранитеља у палати Влахерне, али се помињу пре и после овог периода. ${ }^{46}$ Штавише, у XIV веку Варезима је у Влахернској палати било поверено чување цареве спаваће собе и главне сале за пријеме. ${ }^{47}$

И Англосаксонци су учествовали у чувању царских палата, што се види из Ордерикове тврдње да је Алексије њиховом чувању потчинио своју главну палату; ${ }^{48}$ из овог навода тешко је закључити да ли је Ордерик мислио на Велику палату или Влахерну, али то није од суштинске важности за ову анализу.

\section{Учешће у церемонијама}

Као телохранитељи који су свугде пратили цара, Варези су били учесници многих дворских и градских церемонија. Велики део сваког дана цар и дворани су проводили у строго утврђеним церемонијама, које су у Византији, пре свега, биле знак да државни механизам сврсисходно функционише.

Једна од церемонија у којој затичемо Вареге комнинског доба јесте поменути тријумфални улазак василевса: када је Манојло I тријумфално улазио у Антиохију (1159), пратила га је, по обичају, велика дружина пелекофора. ${ }^{49}$ Својевремено, Варези су учествовали и у тријумфланој процесији севаста Стефана, пошто је овај угушио Манијакисов устанак. ${ }^{50}$

Поред тријумфа, Варези су учествовали и у оружаним смотрама у престоници. Око 1030, у Цариграду је одржана оружана парада, на којој је сваки припадник војник показивао своје оружје. На тој паради је Торстен секиром убио Торберна. Могуће је да су такве параде постојале и у комнинско доба. ${ }^{51}$

Варези су имали и улогу церемонијалних царевих стражара онда када је он примао стране изасланике и домаће високе чиновнике. У комнинско доба, пример такве улоге види се у опису пријема селџучких изасланика који даје Ана Комнина: око василевса Алексија, који је седео на трону, дворани задужени за церемонијал

\footnotetext{
${ }^{43}$ Nicephore Bryennios Histoire, ed. P. Gautier, Bruxelles 1975, 123; S. Blöndal, Varangians, 19, 119.

${ }^{44}$ M. Angold, Empire, 211.

${ }^{45}$ Пол Магдалино, Средњовековни Цариград. Студија о развоју урбаних структура, Београд 2001, 84.

${ }^{46}$ S. Blöndal, Varangians, 162.

${ }^{47}$ M. Bartusis, Army, 273.

${ }^{48}$ Order., vol. II, 172.

${ }^{49}$ Cinn., 187.

${ }^{50}$ S. Blöndal, Varangians, 103.

${ }^{51}$ Ibid., 203.
} 
распоредили су војнике према народности, па су тако наместили у ред и пелекофоре, и тек након тога уведени су изасланици селџучког султана. ${ }^{52}$ И у XIV веку, Варези су били присутни онда кад василевс прима стране изасланике и високе чиновнике. ${ }^{53}$

Варешки телохранитељи у XIV веку окруживали су цара у свакодневним јутарњим процесијама, при којима је цар ишао из Велике палате у храм св. Софије. Процесију су чинили високи функционери царства и одабране аристократе. У току процесије, цар се заустављао на појединим местима да би саслушао излагања чиновника, потписао поједине указе, примио стране изасланике, произвео појединце у нова звања и примио писане жалбе поданика. Када би цар у цркви сео на трон, Варези око њега ставили би на рамена секире, које иначе држе у рукама док год цар стоји. ${ }^{54}$ Овакве процесије вршене су и у доба великих државних празника (дан оснивања Цариграда, рођендани цара и савладара, крунисања цара и савладара, женидба цара). ${ }^{55}$ У веку XIV веку постојао је и обичај да Варези цара пре крунисања подигну на штит како би га народ акламацијом прогласио за цара, ${ }^{56}$ као и да на Божић Варези пожеле цару дуг живот на свом родном језику тј. енглеском. ${ }^{57}$ Немогуће је рећи који су од ових варешких обичаја постојали у комнинско доба, јер комнински извори не помињу ниједан од њих, али није немогуће да су неки од њих и тада постојали.

\section{Хапшење и чување важних затвореника}

Као најповерљивији људи из цареве војне пратње, Варези су вековима имали непопуларну улогу да у име цара хапсе и чувају политички важне појединце, као и да при ислеђивању спроводе мучење. Када је Исак I дошао у сукоб са патријархом Михаилом Керуларијем, он је послао одред Варега да га ухапсе; Варези су за време литургије свукли патријарха са престола и на магарцу га довели до цара. ${ }^{58}$ Варези су 1273. похапсили важне противнике Уније, па су их у кули Анема и чували. Када 1280. монах Јован Кортис није хтео да призна учешће у завери, Варези су га по царевој заповести мучили како би извукли признање. Битно је да су Варези били и чувари ахајског кнеза Гијома II. ${ }^{59}$

У комнинско доба, Вареге видимо како се (1183) по наредби Андроника Комнина спремају да ухапсе тројицу судија који су одбили да суде царици-мајци Марији за заверу. ${ }^{60}$ Вареге у улози чувара важних политичких заточеника видимо

\footnotetext{
${ }^{52}$ Alexias, 438.

${ }^{53}$ S. Blöndal, Varangians, 179.

${ }^{54}$ M. Bartusis, Army, 282; S. Blöndal, Varangians, 181; М. МекКормик, Цар, 312.

${ }_{55}$ Aleksandra Čekalova, Margarita Poljakovska, Život i običaji u vizantijskom društvu, Beograd 2003, 144.

${ }^{56}$ S. Blöndal, Varangians, 181.

${ }^{57}$ M. Bartusis, Army, 282; A. Vasiliev, Immigration, 59. Као што је добро познато, у ово време већину Варега више нису више сачињавали Нордијци, него Енглези.

${ }^{58}$ S. Blöndal, Varangians, 109.

${ }^{59}$ Ibid., 173.

${ }^{60}$ Chon., 266.
} 
онда када је свргнути протосеваст Алексије остављен на чување Германима који носе секире. ${ }^{61}$ Као потенцијалне мучитеље ухапшених, Варези се могу видети у Аниној приповести о завери Соломона и Анеме. Михаило Анема и Јован Соломон (око 1100) ухапшени су под оптужбом да су сковали заверу да убију цара. Одведени су пред царевог брата севастократора Исака, који је Соломону рекао да ће бити подвргнут неподношљивим мукама ако не ода остале заверенике. На то је Соломон погледао Вареге око Исака и задрхтао, те је ускоро признао основаност оптужбе. ${ }^{62}$

\footnotetext{
${ }^{61}$ Ibid., 248-249.

${ }^{62}$ Alexias, 374.
} 


\title{
VARANGIAN MERCENARIES AS GUARDIANS OF COMNENIAN EMPERORS
}

\begin{abstract}
Summary
The paper is a reconstruction of main features of Varangian guarding service under Comnenian emperors in Constantinople (1081-1185), referring mainly to their role in protection of the emperor both in the capital and on the battlefield. It also deals with some relative questions (Varangian role in guarding the palace, and their role in ceremonies), and details concerning their daily life. The paper is based on data from Byzantine and Western sources (both Latin and Nordic).
\end{abstract}

Keywords: medieval mercenaries, the twelfth century, Varangians, Byzantine army. 